\title{
Minimization of Losses and Improving Stability of High Tension Network using Load Flow Analysis
}

\author{
Tariq Ahmad ${ }^{1}$, Inzamam Ul Haq ${ }^{2}$, Ahmad Amin ${ }^{3}$, Abdul Basit ${ }^{4}$ \\ ${ }^{1,2,3}$ Research Assisstants, USPCAS-E, UET Peshawar, Pakistan \\ ${ }^{4}$ Assistant Professor, USPCAS-E UET Peshawar, Pakistan \\ tariq.ahmad839@yahoo.com¹, inzee@live.com ${ }^{2}$, ahmadamin019@gmail.com ${ }^{3}$, abdul.basit@uetpeshawar.edu.pk ${ }^{4}$ \\ Received: 07 July, Revised: 16 July, Accepted: 21 July
}

\begin{abstract}
Accessibility of electric power has been the most dominant source for helping social, economic and industrial improvements of any state. From generation station to the feeders and consumers transmission lines are used to carry the power. Pakistan's current energy system is very weak and requires adequate attention, most of it requires upgrading of the transmission scheme. An real-time issue such as voltage degradation, severe outages and system stabilization of a distribution company's is evaluated here. Some of the serious points are evaluated and also the causes discovered for large losses. After analysis using ETAP simulation load flow analysis was carried out and different methodologies were proposed like addition of distributed generation (Micro hydro, PV, Wind etc.) at the load end to how economically we can mitigate these contingencies and make power system more safe and stable. We discovered the most possible, cost-effective alternatives for a certain serious area after full assessment.
\end{abstract}

Keywords - Technical Losses, Energy, Power Losses, T\&D Losses, NTDC, DISCOs, Advance Metering.

\section{INTRODUCTION}

An essential need for the industrial and economic improvement of any country is the electrical power. Electrical power can be classified in various types, yet the most significant sort is the electrical energy [1]. A contemporary and educated society is dependent on the utilization of electrical energy badly. Tasks, which relates with the generation of electricity, distribution to the stations, consumers and transmission of electricity must be dole out the most importance in the national arranging technique of any country due to the significance of electrical energy to the social and economic improvement of the community $[2,3]$. Transmission line connects the generation of electrical energy with the substations in power network and is one of the important part of power system; The exploration, calculation and mitigation of transmission and distribution losses in these networks are of incredible worry to electrical engineers $[4,5]$. PESCO is one of the important distribution company in total ten companies of Pakistan which has 34\% losses [6], the second most in term of losses in all the ten distribution companies.
Electrical power is basically required for the development of any nation [7]. To keep up the generation of electric power at satisfactory dimension the power must be transmitted in appropriate structure and quality to the users. Pakistan's Power Sector is, and has been for a long time, looked by noteworthy difficulties [8]. These incorporate restricted accessibility of dependable and reasonable electric power, aging and insufficient distribution and transmission systems and utility strategies and practices that seriously fall behind those of present day utilities somewhere else on the planet. Besides a current-day, innovation foundation that can empower proficient, back-office activities, for example, dealing with client administration solicitations isn't in proof.

Hazara circle is the 2nd largest circle of PESCO. It contains 14 No of 132KV GSS, 3 No of 66KV GSS and 3 no of $33 \mathrm{KV}$ GSS. After the complete analysis of Hazara network it is found that some of the week points need proper attention for that all the required data has been collected from different points and by using ETAP simulation load flow analysis is done which give a clear a contrast picture of the whole network. Some points were found in very stress and unstable conditions. After the whole analysis different methodology were proposed to take remedial action that how to avoid these stresses (over loading, losses, and force load shedding). After the load flow analysis (LFA) using ETAP many methods were proposed like Integration at load end of Micro Hydro, PV, Wind and Hydel generation that how to remove such type of contingencies from this system, and how to improve system stability. In last the most feasible and long term methods were also proposed, up gradation of $132 \mathrm{KV}$ GSS Mansehra to 220KV GSS, Double the Circuit, Renewable integration, bundling, and conductor replacement. But the most economical is the conductor replacement from LYNX to LION conductor.

Electrical energy distribution sector is considered as the poorest connection in the whole power system. Distribution losses are roughly 50 percent while Transmission losses are around 17 percent [9]. Distribution as well as Transmission losses are sorted into two kinds.

\section{A. Technical Losses}

Technical losses depends on network characteristics and also on operation mode, these losses are ordinarily 22.5 percent 
[9]. Technical losses are further portioned into two sub categorize.

i. $\quad$ Fixed/Permanent Technical losses

- Corona losses

- Losses of continuous load measuring elements

- Leakage Current losses

- Losses of continuous load control elements

- Open-circuit losses

- Dielectric losses

ii. $\quad$ Variable Technical losses

Variable losses change with the distribution of electrical energy and are, all the more precisely, proportionate to the square of the current. so, a $1 \%$ change in current prompts a change over $1 \%$ [7].

- Between 0.66 and 0.75 of specialized (or physical) losses are variable Losses in a distribution systems.

- Losses of contact resistance.

- Joule losses at each voltage level.

- Cables and cross sectional area of transmission lines are inversely related to losses. This prompts direct exchange between capital expenses cost and expense of losses. It has been prescribed that best normal utilization rate on a distribution stations that considers the expense of losses in its structure could be as low as 30 percent.

- Impedance losses.

Pakistan has an extraordinary rate of electric distribution and transmission losses and is ranked in the top 14th among 131 countries [10]. In figure 1, the statistics of losses in transmission and distribution is shown from 1971 to 2010 according to World Bank analysis.

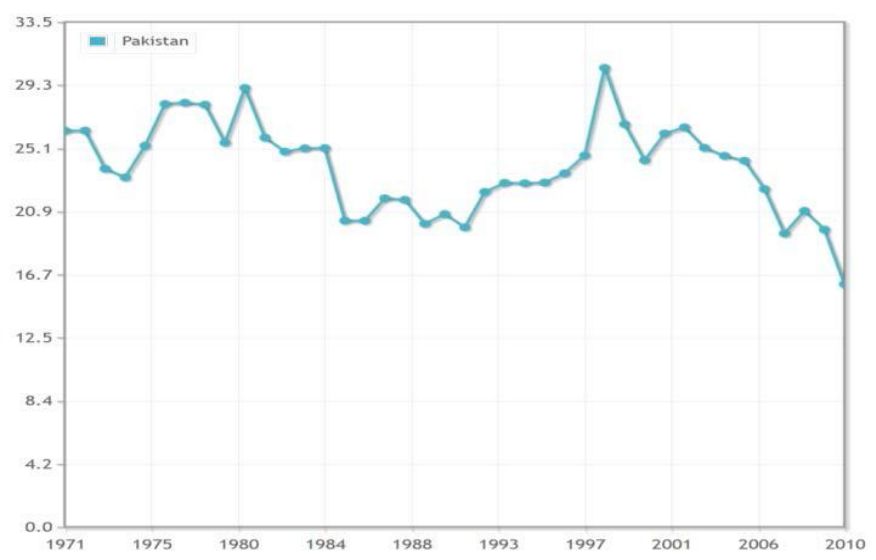

Figure 1. Statistics of losses in transmission and distribution from 19712010 [6].

8.8 is the world average, T\&D losses in the range of 6 to 8 per centare considered normal in electrical world [11]. PESCO is one of the most important distribution company in total discos, while the losses in PESCO is too much high and it is on no 2nd in losses in total discos which is quite unsatisfactory and mostly affects the consumers as well as the company.
These losses are technical and non-technical losses. Some of the places under PESCO need proper attention because the system is old and week.

Load shedding is nowadays a great problem because the deficiency of power in Pakistan is increasing from 1998 [12]. The present operating system is quite weak and unable to sustain more integration, some of the points in system are too weak and proper attention is required, load shedding is also increasing because the generation deficiency but there are also some places where unscheduled load shedding take place which is a big problem and this is due to the system old vintage equipment's so in this project we will find and show some severe places and then propose some methods on how to make those weak points to stable position.

\section{METHODOLOGY}

In this research analysis of a complete power circle and load flow analysis is done using ETAP simulation. It is easily found that some places in the whole network need proper planning and attention, the whole company comprises of many circles of network but Hazara circle is in more stress condition because of its outages and voltage un-stability. In Hazara circle $132 \mathrm{KV}$ lines are spread from Burhan (220KV) GSS to Haripur, Abbottabad, Mansehra and Balakot, from Burhan to Haripur and then Mansehra two circuits line are coming while from Abbottabad to Mansehra the line is single circuit, its conductor is LYNX and its current carrying capacity is $480 \mathrm{~A}$, The transmission line spread from Abbottabad to Mansehra and then leads to Muzafarabad.

Most of the time when the load increase from 480A or any contingencies occurs due to which system burden increase due to which the conductor starts heating. So to avoid such type of conditions the grid operator used only force load shedding(Outages) which is not the actual solution of this problem.

For vanishing this problem we take the ratting of whole the system and conductor specification, and by ETAP simulation we analyze it by doing its load flow analysis. After analysis it is fond that what was the actual cause of these problems and how we can erase these from over system. For this we proposed different models and methods which are given below:

- Renewable Integration

- Conventional plant integration

- Up-gradation of Mansehra 132KV GSS to 220KV GSS

- Doubling the circuit

- Bundling of transmission line

- Conductor Replacement

\section{MODELING}

The transmission lines are demonstrated by methods for the parameters such as capacitance, inductance, conductance and resistance. The impedance of the transmission lines are due to the inductance and resistance while the admittance are due to 
the parallel combination of conductance and capacitance. These four electrical elements play an important role in transmission and distribution system [13].

\section{A. Resistance}

The resistance of conductor are negligible[14]. Resistor play significant role in short distance lines. Line current and resistance losses are directly related a current increases the losses are also increases (I2R loss). At the point when the current surpass a specific threshold the heat created because of losses begins to liquefy the conductor and the conductor turns out to be longer that outcomes in more sag [13]. The current at which the state of conductor is irreversible is called thermal threshold of conductor. Short overhead lines ought to be worked well inside this point of confinement.

The value of the ohmic power loss, is given as

$$
L_{\text {ohmic }}=I^{2} R \quad \mathrm{KW} / \mathrm{Km} / \text { Phase }
$$

Where

\section{Indicates current.}

$R$ Indicates resistance.

\section{B. Inductance}

The line inductance (reactance) is more overwhelming in long as well as in medium distance than resistance[15]. The estimation of current that conducts in a conductor is related with another parameter, inductance. The electrical symbol for inductor is $\mathrm{L}$ and its unit is Henry $(\mathrm{H})$. The value of inductor is usually very small, milli Henry $(\mathrm{mH})$. Companies often indicate the inductance per kilometer or mile of transmission lines and cables.

\section{$i$. Inductance of a two-wire line}

A single phase line consists of two conductors ' $a$ ' and ' $b$ ' (Phase \& Neutral) having equal radius ' $r$ ' is considered. The conductors are situated at a distance ' $D$ ' meters. The diagram below shows the cross section of the conductors. The current flow in conductors is considered in opposte direction as the neutral conductor is return path for the other.

The flux linkages of conductor ' $a$ ' is given by the formula [11][13]

$$
\lambda_{a}=2 \times 10^{-7}\left[I_{a} \operatorname{In} \frac{1}{D_{a a}}+I_{b} \frac{1}{D_{a b}}\right]
$$

Where,

$$
\begin{aligned}
& I_{a}=+I \\
& I_{b}=-I \\
& D_{a a}=r^{\prime} \\
& D_{a b}=D
\end{aligned}
$$

Substituting these values in above equation

$$
\begin{aligned}
\lambda_{a} & =2 \times 10^{-7}\left[I_{a} \operatorname{In} \frac{1}{r^{\prime}}-I_{b} \frac{1}{D}\right] \\
& =2 \times 10^{-7} \operatorname{IIn} \frac{D}{r^{\prime}}
\end{aligned}
$$

Similarly, the flux linkage of conductor ' $b$ ' will be

$$
\lambda_{b}=2 \times 10^{-7} \operatorname{IIn} \frac{D}{r^{\prime}}
$$

The inductance of conductor ' $a$ '

$$
L_{a}=2 \times 10^{-7} \ln \frac{D}{r^{\prime}} H / m
$$

Similarly, the inductance of conductor ' $b$ '

$$
L_{b}=2 \times 10^{-7} \operatorname{In} \frac{D}{r^{\prime}} H / m
$$

Inductance per conductor

$$
L=L_{a}=L_{b}=2 \times 10^{-7} \operatorname{In} \frac{D}{r^{\prime}} H / m
$$

Inductance of both conductors is given by the formula

Loop inductance $=L_{a}+L_{b}=2 \times 2 \times 10^{-7} \operatorname{In} \frac{D}{r^{\prime}} \mathrm{H} / \mathrm{m}$

$$
=4 \times 10^{-7} \operatorname{In} \frac{D}{r}, H / m
$$

The total inductance of a two-wire line is double the inductance of an individual conductor.

\section{ii. Inductance of symmetrical three-phase line}

In symmetrical three-phase line, all the conductors are placed at the corners of the equilateral triangle. This type of arrangement of conductors is also known as 'equilateral spacing', as shown in the diagram below.

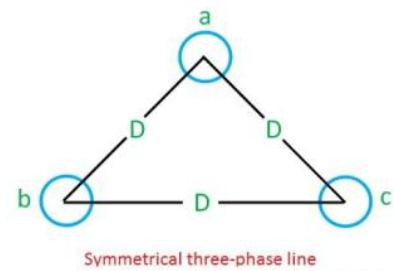

Consider ' $\mathrm{D}$ ' is the spacing between the conductors and ' $\mathrm{r}$ ' is the radius of each conductor. Then the equation of conductor ' $a$ ' flux linkages will be:

$$
\lambda_{a}=2 \times 10^{-7}\left(I_{a} \operatorname{In} \frac{1}{D_{a a}}+I_{b} \operatorname{In} \frac{1}{D_{a b}}+I_{c} \operatorname{In} \frac{1}{D_{a c}}\right)
$$

In this case

$$
\begin{aligned}
& D_{a b}=D_{b c}=D_{a c}=D \\
& D_{a a}=r^{\prime} \\
& \lambda_{a}=2 \times 10^{-7}\left(I_{a} \operatorname{In} \frac{I}{r^{\prime}}+I_{b} \operatorname{In} \frac{1}{D}+I_{c} \frac{1}{D}\right)
\end{aligned}
$$

The algebraic sum of the currents in conductors of a threewire system is zero.

$$
\begin{gathered}
I_{a}+I_{b}+I_{c}=0 \\
I_{a}=-I_{b}-I_{c} \\
I_{a}=-\left(I_{b}+I_{c}\right)
\end{gathered}
$$

So the flux equation becomes 


$$
\begin{aligned}
\lambda_{a}= & 2 \times 10^{-7} \times\left(I_{a} \operatorname{In} \frac{1}{r^{\prime}}+\left(I_{b}+I_{c}\right) \operatorname{In} \frac{I}{D}\right) \\
\lambda_{a} & =2 \times 10^{-7}\left(I_{a} \operatorname{In} \frac{1}{r^{\prime}}-I_{a} \operatorname{In} \frac{1}{D}\right) \\
& =2 \times 10^{-7} \times I_{a}\left(\operatorname{In} \frac{1}{r^{\prime}}-\operatorname{In} \frac{I}{D}\right)
\end{aligned}
$$

Using the formula

$$
\left(\operatorname{In} m-\operatorname{In} n=\operatorname{In} \frac{m}{n}\right)
$$

The inductance of conductor, ' $a$ ' is

$$
\lambda_{a}=\frac{\lambda}{I_{a}}=2 \times 10^{-7} \operatorname{In} \frac{D}{r^{\prime}} H / m
$$

The inductance of conductor ' $b$ ' and ' $c$ ' will also be the same as that of ' $a$ '. The inductance of the three-phase line is equal to the two-wire line.

\section{iii. Inductance of unsymmetrical three-phase line}

A Three-phase line is said to be unsymmetrical when its conductors are placed at different distances. Such arrangement of conductors is most common in practice because of their cheapness and convenience in design and construction. Consider a three-phase unsymmetrical line, having different spacing between their conductors where the radius of each conductor is $r$. It is shown in the diagram below [16].

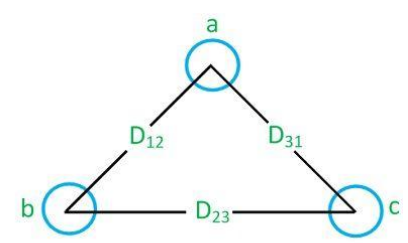

Unsymmetrical three-phase line

Flux linkage in ' $a$ ' is expressed by the formula

$$
\lambda_{a 1}=2 \times 10^{-7}\left(I_{a} \operatorname{In} \frac{1}{r^{\prime}}+I_{b} \operatorname{In} \frac{I}{D_{12}}+I_{b} \operatorname{In} \frac{1}{D_{31}}\right)
$$

Flux linkage in conductor ' $a$ ' due to ' $b$ ' is given by the formula

$$
\lambda_{a 2}=2 \times 10^{-7}\left(I_{a} \operatorname{In} \frac{1}{r^{\prime}}+I_{b} \operatorname{In} \frac{1}{D_{23}}+I_{c} \frac{1}{D_{12}}\right)
$$

Flux linkage in conductor ' $a$ ' due to 'c' is given by

$$
\lambda_{a 3}=2 \times 10^{-7}\left(I_{a} \operatorname{In} \frac{1}{r^{\prime}}+I_{b} \operatorname{In} \frac{1}{D_{23}}+I_{c} \operatorname{In} \frac{1}{D_{23}}\right)
$$

The average value of flux linkages of ' $a$ ' is

$$
\lambda_{a}=\frac{1}{3}\left(\lambda_{a 1}+\lambda_{a 2}+\lambda_{c}\right)
$$

$$
\begin{aligned}
& \lambda_{a}=\frac{2}{3} \times 10^{-7} {\left[\left(I_{a} \operatorname{In} \frac{1}{r^{\prime}}+I_{b} \operatorname{In} \frac{1}{D_{13}}+I_{c} \frac{1}{D_{31}}\right)+\left(I_{a} \operatorname{In} \frac{1}{r^{\prime}}+I_{b} \operatorname{In} \frac{1}{D_{23}}+I_{12} \frac{1}{D_{12}}\right)\right.} \\
&+\left.\left(I_{a} \operatorname{In} \frac{1}{r^{\prime}}+I_{b} \operatorname{In} \frac{1}{D_{31}}+I_{c} \operatorname{In} \frac{1}{D_{23}}\right)\right] \\
& \lambda_{a}=\frac{2}{3} \times 10^{-7}\left[3 I_{a} \operatorname{In} \frac{I}{r^{\prime}}+I_{b} \operatorname{In} \frac{1}{D_{12} D_{23} D_{31}}+I_{c} \operatorname{In} \frac{1}{D_{12} D_{23} D_{31}}\right] \\
& \lambda_{a}=\frac{2}{3} \times 10^{-7}\left[3 I_{a} \operatorname{In} \frac{1}{r^{\prime}}-I_{a} \operatorname{In} \frac{1}{D_{12} D_{23} D_{31}}\right]
\end{aligned}
$$

Since for balanced conditions

$$
\begin{gathered}
I_{a}+I_{b}+I_{c}=0 \\
I_{b}+I_{c}=-I_{a} \\
\lambda_{a}=2 \times 10^{-7}\left[I_{a} \operatorname{In} \frac{1}{r^{\prime}}+\frac{1}{3} I_{a} \operatorname{In}\left(D_{12} D_{23} D_{31}\right)\right]
\end{gathered}
$$

By using formula

$$
\frac{1}{2} \operatorname{In} m=\operatorname{In} m^{\frac{1}{2}} \quad \lambda_{a}=2 \times 10^{-7} \times I_{a} \operatorname{In} \frac{\left(D_{12} D_{23} D_{31}\right)^{\frac{1}{3}}}{r^{\prime}}
$$

The average inductance of phase a is

$$
L_{a}=\frac{\lambda_{a}}{I_{a}}=2 \times 10^{-7} \times \operatorname{In} \frac{\left(D_{12} D_{23} D_{31}\right)^{\frac{1}{3}}}{r^{\prime}} \mathrm{H} / \mathrm{m}
$$

Similarly,

$$
L_{b}=L_{c}=2 \times 10^{-7} \times \operatorname{In} \frac{\left(D_{12} D_{23} D_{31}\right)^{\frac{1}{3}}}{r^{\prime}} \mathrm{H} / \mathrm{m}
$$

Thus, it is found that the values of the inductance for the three phases are equalized by transpositions.

\section{Capacitance of Transmission Line}

Transmission line conductors creates a capacitor between them. The transmission line conductors act as a parallel plate of capacitor and the air act like a dielectric medium between them. The line capacitance give rise to the leading current between the conductors. It depends on the length of the conductor. Capacitance of two-wire line is given as

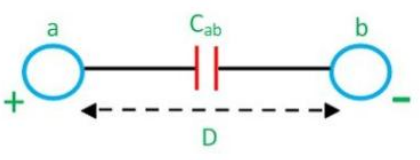

Line-to-line Capcitance

$$
C_{a b}=\frac{q_{a}}{V_{a b}}=\frac{\pi \varepsilon}{\operatorname{In} \frac{D}{r}} F / m
$$

$\mathrm{C}_{\mathrm{ab}}$ is referred as line-to-line-capacitance.

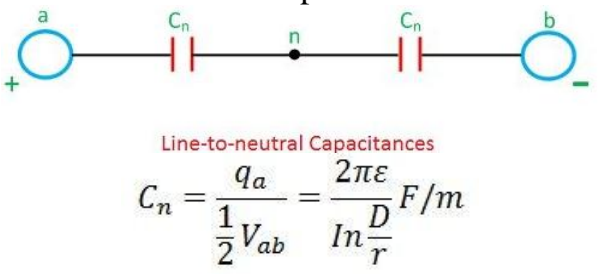


Capacitance of the symmetrical three-phase line-to-neutral is,

$$
\begin{gathered}
C_{n}=\frac{q_{n}}{V_{a n}}=\frac{2 \pi \varepsilon_{0}}{\operatorname{In} \frac{D}{r}}=\frac{1}{18 \times 10^{9} \operatorname{In} \frac{D}{r}} F / m \\
C_{n}=\frac{1}{18 \operatorname{In} \frac{D}{r}} \mu F / k m \text {---equ(9) }
\end{gathered}
$$

The symmetrical three-phase line capacitance is same as that of the two-wire line.

\section{SMULATION AND RESUltS}

\section{A. Present Condition}

Figure 3 shows the Power Grid which supplies power to the $132 \mathrm{kV}$ Haripur GSS (Black in colour). Then by double circuit lines it feed power to $132 \mathrm{KV}$ Abbottabad GSS (Pink in colour) and then from $132 \mathrm{KV}$ Abbottabad single circuit line feed power to $132 \mathrm{KV}$ Mansehra GSS, Hazara network is spread from Burhan 220KV GSS to Muzaffarabad and up to Pattan.

Simulation through ETAP(Electrical transient analysis program) clearly shows that the present operating high tension network is overloaded due to which system bus voltages reduces to $119 \mathrm{KV}$ from nominal $132 \mathrm{KV}$. Black colour of bus show Normal bus voltage and bus is in safe position, pink colour of bus shows less severe condition and the bus voltage is between $124 \mathrm{KV}$ to $128 \mathrm{KV}$. The red colour show most severe condition whenever the system overloaded and the bus voltage less the $123 \mathrm{KV}$.

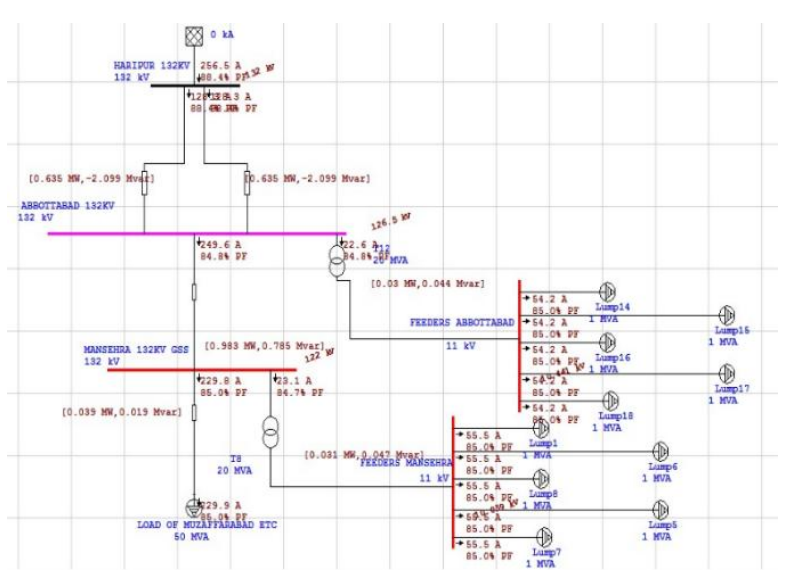

Figure 2. Simulation of present conditions of 132 KV GSS of Hazara Division.

TABLE I. ACTUAL CONDITION OF THE SYSTEM

\begin{tabular}{|l|l|l|l|}
\hline Name of GSS & Voltage level & $\begin{array}{l}\text { Color of } \\
\text { Buses }\end{array}$ & Condition \\
\hline Haripur(132KV) & $132 \mathrm{KV}$ & Black & Healthy \\
\hline $\begin{array}{l}\text { Abbottabad } \\
(132 \mathrm{KV})\end{array}$ & $128 \mathrm{KV}$ & Pink & $\begin{array}{l}\text { Marginal/Under } \\
\text { Voltage/Over } \\
\text { load }\end{array}$ \\
\hline Mansehra (132KV) & $120 \mathrm{KV}$ & Red & $\begin{array}{l}\text { Critical/Severe } \\
\text { Under } \\
\text { voltage/Overload }\end{array}$ \\
\hline $\begin{array}{l}\text { Abbottabd Feeders } \\
(11 \mathrm{KV})\end{array}$ & $9.8 \mathrm{KV}$ & Pink & $\begin{array}{l}\text { Margnal/Under } \\
\text { Voltage/Over } \\
\text { load }\end{array}$ \\
\hline Mansehra (11KV) & $9.0 \mathrm{KV}$ & Black & $\begin{array}{l}\text { Severe Under } \\
\text { voltage/Overload }\end{array}$ \\
\hline
\end{tabular}

From the figure we can easily see that the Haripur GSS is in normal operating position while the Abbottabad is in less severe state, while Mansehra 132KV GSS is in most severe state and proper attention required. This overload is due to some factors, which are, single circuit line from Abbottabad GSS to Mansehra GSS, old vintage system, not proper designing.

Now how to overcome this overloading and force load shedding problems we have proposed different methods and also by simulation we shows there actual results.

\section{B. By Integration of Micro Generation}

To overcome these effects the first method is by penetrating power from micro hydro generation. From the simulation in Figure 4 we can easily see that all the buses voltages come to its nominal position if we penetrate power using micro hydro at Mansehra 132KV GSS. All the buses in Fig 2 are in black colour and at nominal voltage level.

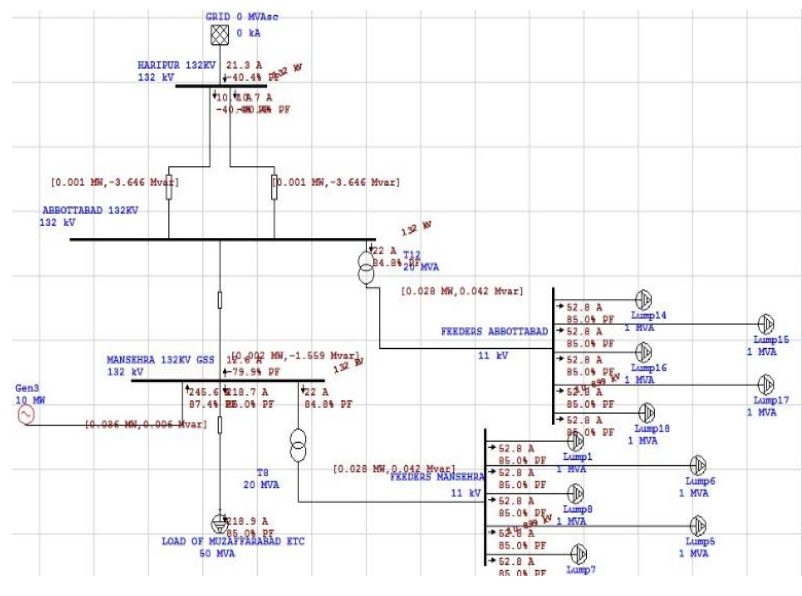

Figure 3. Integration of micro hydro to Mansehra $132 \mathrm{KV}$ GSS.

TABLE II. RESUlTS AFTER INTEGRATION OF MicRo Hydros TO MANSEHRA GSS ESULTS

\begin{tabular}{|l|l|l|l|}
\hline Name of GSS & Voltage level & Color of Buses & Condition \\
\hline Haripur(132KV) & $132 \mathrm{KV}$ & Black & Healthy \\
\hline $\begin{array}{l}\text { Abbottabad } \\
(132 \mathrm{KV})\end{array}$ & $132 \mathrm{KV}$ & Black & Healthy \\
\hline $\begin{array}{l}\text { Mansehra } \\
(132 \mathrm{KV})\end{array}$ & $132 \mathrm{KV}$ & Black & Healthy \\
\hline $\begin{array}{l}\text { Abbottabd } \\
\text { Feeders }(11 \mathrm{KV})\end{array}$ & $11 \mathrm{KV}$ & Black & Healthy \\
\hline Mansehra $(11 \mathrm{KV})$ & $11 \mathrm{KV}$ & Black & Healthy \\
\hline
\end{tabular}

\section{By Integration Of Renewable (PV)}

The effect of overloading, force load shedding or any other contingencies from this system can also be reduce by renewable integration, in Figure 5, shows how these effects are reduce from system by integration of $\mathrm{PV}$. 


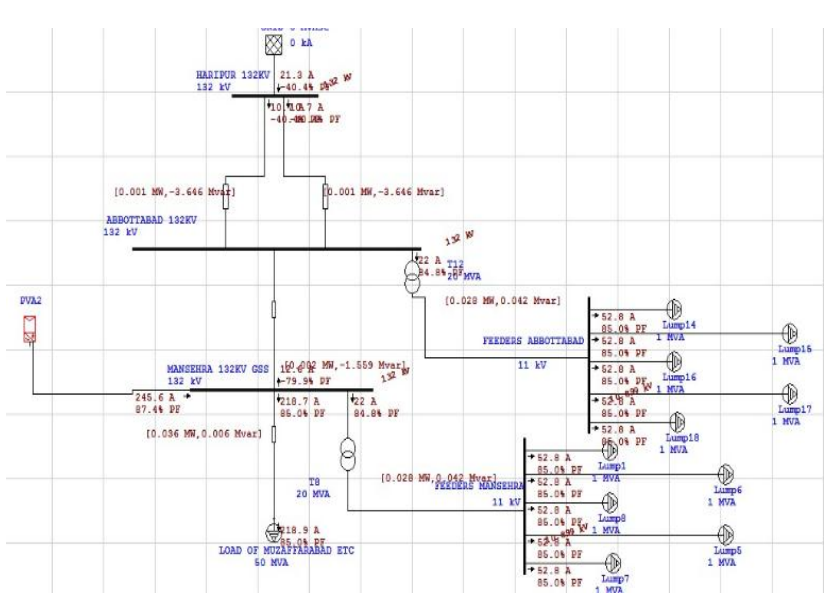

Figure 4. Integration of PV to Mansehra $132 \mathrm{KV}$ GSS.

TABLE III. BY INTEGRATION OF RENEWABLES PVS

\begin{tabular}{|l|l|l|l|}
\hline Name of GSS & Voltage level & Color of Buses & Condition \\
\hline Haripur(132KV) & $132 \mathrm{KV}$ & Black & Healthy \\
\hline $\begin{array}{l}\text { Abbottabad } \\
(132 \mathrm{KV})\end{array}$ & $132 \mathrm{KV}$ & Black & Healthy \\
\hline $\begin{array}{l}\text { Mansehra } \\
(132 \mathrm{KV})\end{array}$ & $132 \mathrm{KV}$ & Black & Healthy \\
\hline $\begin{array}{l}\text { Abbottabd } \\
\text { Feeders }(11 \mathrm{KV})\end{array}$ & $11 \mathrm{KV}$ & Black & Healthy \\
\hline Mansehra $(11 \mathrm{KV})$ & $11 \mathrm{KV}$ & Black & Healthy \\
\hline
\end{tabular}

By integration of renewable PVs, from the simulation results it is cleared that the system become more stable as it is taking load from near by PVs generation and transmisiion losses minimized. All the voltages of GSS became stable.

\section{By Integration Of Renewable (Wind Generation)}

From figure 6 , we can see that by integrating wind power with the present operating system we can erase all the contingencies.

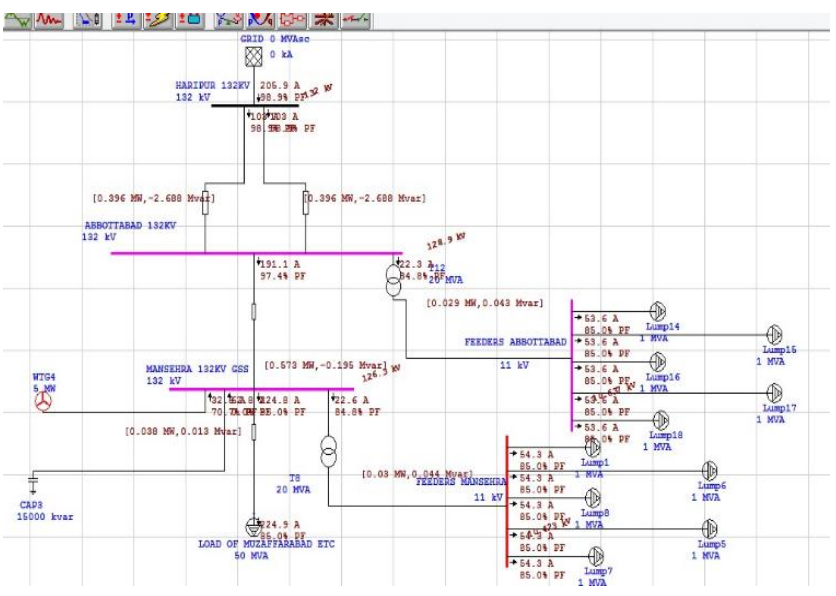

Figure 5. Integration of Wind energy to Mansehra 132 KV GSS.

TABLE IV. By INTEGRATION WIND POWER PLANT

\begin{tabular}{|l|l|l|l|}
\hline Name of GSS & Voltage level & $\begin{array}{l}\text { Color of } \\
\text { Buses }\end{array}$ & Condition \\
\hline Haripur(132KV) & $132 \mathrm{KV}$ & Black & Healthy \\
\hline Abbottabad & $130 \mathrm{KV}$ & Black & Healthy \\
\hline
\end{tabular}

\begin{tabular}{|l|l|l|l|}
\hline$(132 \mathrm{KV})$ & & & \\
\hline Mansehra (132KV) & $127 \mathrm{KV}$ & Pink & $\begin{array}{l}\text { Under Voltage/ } \\
\text { Over load }\end{array}$ \\
\hline $\begin{array}{l}\text { Abbottabd Feeders } \\
(11 \mathrm{KV})\end{array}$ & $9.8 \mathrm{kV}$ & Pink & $\begin{array}{l}\text { Under Voltage/ } \\
\text { Over load }\end{array}$ \\
\hline Mansehra $(11 \mathrm{KV})$ & $9.8 \mathrm{KV}$ & Pink & $\begin{array}{l}\text { Under Voltage/ } \\
\text { Over load }\end{array}$ \\
\hline
\end{tabular}

From the results it is clearly seen thatwind Integration of wind generation the system voltage improves a little bit but not came under stable position because of low reliability of wind generation

\section{E. By Doubling The Circuits}

Figure 7 show that if we double the circuit so we can also reduce force load shedding because the load on single circuit is some time beyond the ratting of conductor due to which only one method is used force load shedding, so to vanish this effect we can double the circuit so the load will be divided in two different paths and the bus voltages will be near to nominal

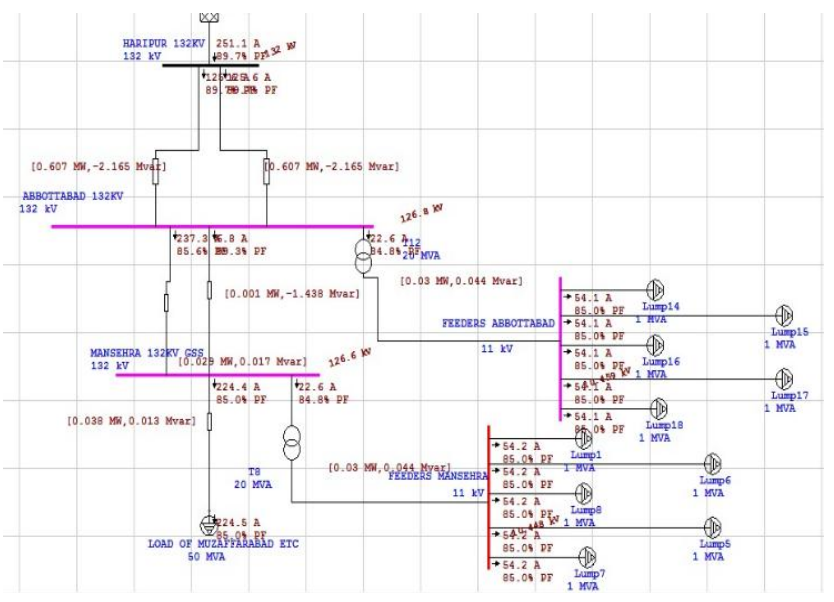

Figure 6. Effect of Circuit doubling

TABLE V. By DOUBLING THE CIRCUIT

\begin{tabular}{|l|l|l|l|}
\hline Name of GSS & $\begin{array}{l}\text { Voltage } \\
\text { level }\end{array}$ & $\begin{array}{l}\text { Color of } \\
\text { Buses }\end{array}$ & Condition \\
\hline Haripur(132KV) & $132 \mathrm{KV}$ & Black & Healthy \\
\hline Abbottabad (132KV) & $128.4 \mathrm{KV}$ & Pink & $\begin{array}{l}\text { Under Voltage/ } \\
\text { Over load }\end{array}$ \\
\hline Mansehra (132KV) & $126.6 \mathrm{KV}$ & Pink & $\begin{array}{l}\text { Under Voltage/ } \\
\text { Over load }\end{array}$ \\
\hline $\begin{array}{l}\text { Abbottabd Feeders } \\
(11 \mathrm{KV})\end{array}$ & $10.5 \mathrm{KV}$ & Pink & $\begin{array}{l}\text { Under Voltage/ } \\
\text { Over load }\end{array}$ \\
\hline Mansehra $(11 \mathrm{KV})$ & $10 \mathrm{KV}$ & Pink & $\begin{array}{l}\text { Under Voltage/ } \\
\text { Over load }\end{array}$ \\
\hline
\end{tabular}

\section{F. By Connecting 132kv Gss To Allai Khwar Power} Plant(220kv)

Allay Khwar Hydropower Plant located in the Battagram District on the Allay Khwar River, is a run-of-the-river project having generation capacity of $121 \mathrm{MW}$. The head of the project is 687 meters. We can also integrate power from Allay khwar power plant to $132 \mathrm{KV}$ Mansehra so by this we can easily stabilize our system to nominal and avoid unnecessary load shedding. Allai khwar power plant generation is in $220 \mathrm{KV}$ so we will use two approaches for this which is given in figure 8 and figure 9 . 


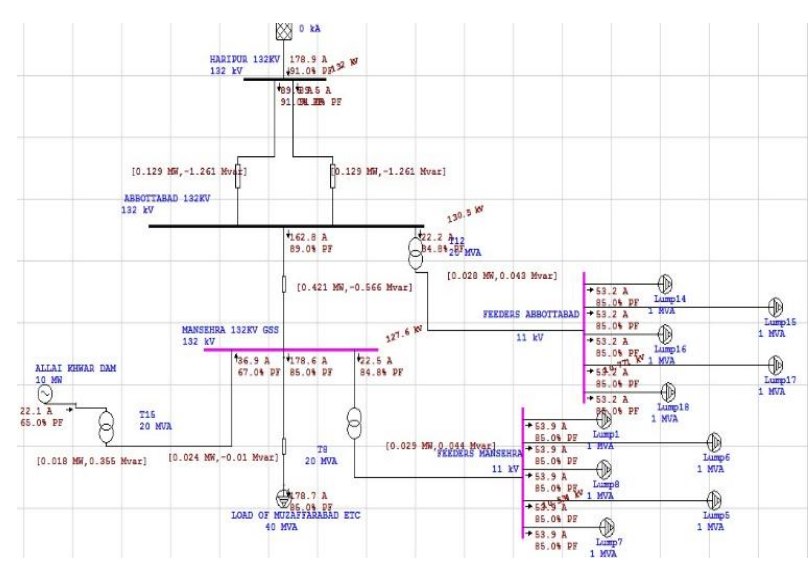

Figure 7. Integration of Mansehra $132 \mathrm{KV}$ GSS to $220 \mathrm{kV}$ Allai Khwar Power Plant (Approach 1).

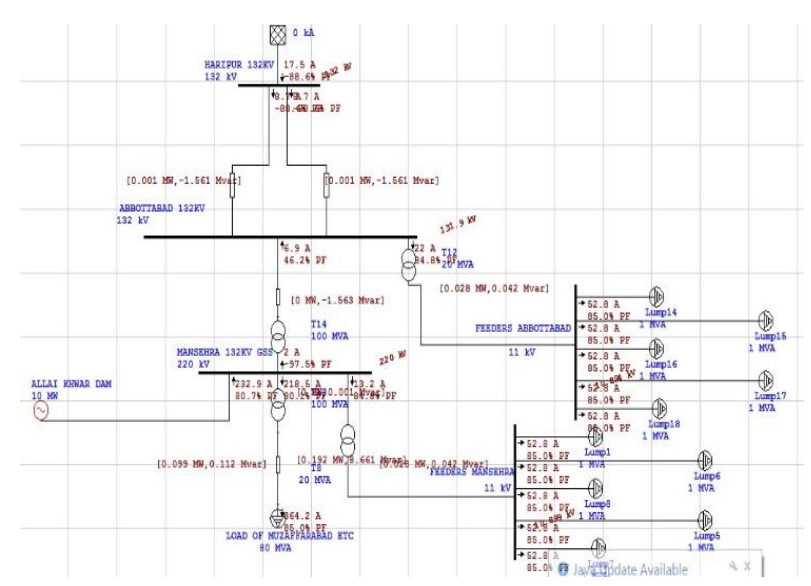

Figure 8. Integration of Mansehra $132 \mathrm{KV}$ GSS to $220 \mathrm{kV}$ Allai Khwar Power Plant (Approach 2).

TABLE VI. InTEgRation OF Hydel POWER POWER STATION

\begin{tabular}{|l|l|l|l|}
\hline Name of GSS & Voltage level & $\begin{array}{l}\text { Color of } \\
\text { Buses }\end{array}$ & Condition \\
\hline Haripur(132KV) & $132 \mathrm{KV}$ & Black & Healthy \\
\hline Abbottabad (132KV) & $132 \mathrm{KV}$ & Black & Healthy \\
\hline Mansehra (132KV) & $132 \mathrm{KV}$ & Black & Healthy \\
\hline $\begin{array}{l}\text { Abbottabd Feeders } \\
(11 \mathrm{KV})\end{array}$ & $11 \mathrm{KV}$ & Black & Healthy \\
\hline Mansehra (11KV) & $11 \mathrm{KV}$ & Black & Healthy \\
\hline
\end{tabular}

\section{G. Conductor Replacement}

The last method which we can use to vanish the effect of overloading and force load shedding is to replace the existing conductor LYNX to LION conductor, mostly time this single circuit from Abbottabad 132KV GSS to Mansehra 132KV GSS is in overloaded position which is responsible for force load shedding, the current carrying capacity of LYNX conductor is $480 \mathrm{~A}$ while the lion conductor is 654A. The max current recorded in summer is $543 \mathrm{~A}$ which is greater than the ratting if LYNX conductor and LION can easily sustain current up to 700A. Due to replacement of conductor the losses on conductor also reduce up to some extent and the system burden reduce quite well in figure 10 to figure 12 all the effect before and after conductor replacement are shown.
TABLE VII. DIFFERENTS CONSUCTORS EFFECTS UPON THE LOSSES

\begin{tabular}{|l|l|l|l|l|l|}
\hline \multicolumn{2}{|l|}{ Code Name } & LYNX & PANTHER & LION & BEAR \\
\hline Al No/mm & $30 / 2.79$ & $30 / 3.00$ & $30 / 3.18$ & $30 / 3.35$ \\
\hline Steel NO/mm & $7 / 2.79$ & $7 / 3.00$ & $7 / 3.18$ & $7 / 3.35$ \\
\hline Weight Kg/Km & 842 & 1001 & 1093 & 1213 \\
\hline $\begin{array}{l}\text { Overall } \\
\text { Diameter }\end{array}$ & $(\mathrm{mm})$ & 19.53 & 21 & 22.26 & 23.45 \\
\hline \begin{tabular}{l} 
Nominal \\
$\begin{array}{l}\text { Cross } \\
\text { sectional } \\
\text { Area }\end{array}$ \\
\hline $\begin{array}{l}\text { Calculated DC } \\
\text { resistane } \Omega / K m\end{array}$
\end{tabular} & 226.2 & 261.53 & 293.85 & 326.11 \\
\hline $\begin{array}{l}\text { Inductive Reactance } \\
\Omega / \text { Km }\end{array}$ & 0.37658 & 0.372045 & 0.36835 & 0.36508 \\
\hline \multicolumn{2}{|l|}{ Current Rating (A) } & 488 & 606 & 654 & 700 \\
\hline
\end{tabular}

TABLE VIII. DIFFERENTS CONSUCTORS EFFECTS UPON THE LOSSES

\begin{tabular}{|c|c|c|c|c|c|}
\hline \multicolumn{2}{|l|}{ Code Name } & LYNX & PANTHER & LION & BEAR \\
\hline \multicolumn{2}{|l|}{ Voltage } & $132 \mathrm{KV}$ & $132 \mathrm{KV}$ & $132 \mathrm{KV}$ & $132 \mathrm{KV}$ \\
\hline \multicolumn{2}{|c|}{ DC Resistance $\Omega / \mathrm{Km}$} & 0.158 & 0.1362 & 0.1171 & 0.10558 \\
\hline \multicolumn{2}{|c|}{$\begin{array}{l}\text { Inductive Reactance } \\
\Omega / \mathrm{Km}\end{array}$} & 0.37658 & 0.37204 & 0.36835 & 0.36508 \\
\hline $\begin{array}{l}\text { Losses in } \\
(\%) \text { Percent } \\
\text { for load } \\
450 \mathrm{~A}\end{array}$ & $\begin{array}{l}\mathrm{P}=\mathrm{I} 2 \\
\mathrm{Z}\end{array}$ & 3.062 & 2.9714 & 2.898 & 2.85 \\
\hline $\begin{array}{l}\text { Losses in } \\
\text { (\%) Percent } \\
\text { for load } \\
550 \mathrm{~A}\end{array}$ & $\begin{array}{l}\mathrm{P}=\mathrm{I} 2 \\
\mathrm{Z}\end{array}$ & 3.74 & 3.6317 & 3.543 & 3.484 \\
\hline $\begin{array}{l}\text { Losses in } \\
(\%) \text { Percent } \\
\text { for load } \\
650 \mathrm{~A}\end{array}$ & $\begin{array}{l}\mathrm{P}=\mathrm{I} 2 \\
\mathrm{Z}\end{array}$ & 4.424 & 4.292 & 4.1872 & 4.117 \\
\hline
\end{tabular}

TABLE IX. SimUlation Results Before Conductor RePlacement

\begin{tabular}{|l|l|l|l|l|l|l|}
\hline $\begin{array}{l}\text { Device } \\
\text { ID }\end{array}$ & Status & $\begin{array}{l}\text { Typ } \\
\mathbf{e}\end{array}$ & $\begin{array}{l}\text { Conditio } \\
\mathbf{n}\end{array}$ & Limit & $\begin{array}{l}\text { Operati } \\
\mathbf{n g}\end{array}$ & $\begin{array}{l}\text { Operati } \\
\text { ng }\end{array}$ \\
\hline Bus 4 & Critical & Bus & $\begin{array}{l}\text { Under } \\
\text { voltage }\end{array}$ & $\begin{array}{l}132 \mathrm{~K} \\
\text { V }\end{array}$ & 120.95 & 91.6 \\
\hline $\begin{array}{l}\text { Mansehra } \\
\text { 132KV } \\
\text { GSS }\end{array}$ & Critical & Bus & $\begin{array}{l}\text { Under } \\
\text { voltage }\end{array}$ & $\begin{array}{l}132 \\
\text { KV }\end{array}$ & 117.8 & 89.2 \\
\hline $\begin{array}{l}\text { Abbottab } \\
\text { ad } \\
132 \text { KV } \\
\text { GSS }\end{array}$ & Critical & Bus & $\begin{array}{l}\text { Under } \\
\text { voltage }\end{array}$ & $\begin{array}{l}132 \\
\text { KV }\end{array}$ & 121.20 & 90.9 \\
\hline $\begin{array}{l}\text { Mansehra } \\
\text { Feeder } \\
11 \mathrm{KV}\end{array}$ & Critical & Bus & $\begin{array}{l}\text { Under } \\
\text { voltage }\end{array}$ & $\begin{array}{l}11 \\
\text { KV }\end{array}$ & 9.99 & 90.9 \\
\hline $\begin{array}{l}\text { T/L ABN } \\
\text { to } \\
\text { Mansehra }\end{array}$ & Critical & Line & $\begin{array}{l}\text { Over } \\
\text { load }\end{array}$ & $450 \mathrm{~A}$ & $563 \mathrm{~A}$ & 125.11 \\
\hline
\end{tabular}




\begin{tabular}{|l|l|l|l|l|l|l|}
\hline $132 \mathrm{KV}$ & & & & & & \\
\hline $\begin{array}{l}\text { Abbottab } \\
\text { ad } \\
\begin{array}{l}\text { Feeder } \\
11 \mathrm{KV}\end{array}\end{array}$ & $\begin{array}{l}\text { Margin } \\
\text { al }\end{array}$ & $\begin{array}{l}\text { BU } \\
\text { S }\end{array}$ & $\begin{array}{l}\text { Under } \\
\text { voltage }\end{array}$ & $\begin{array}{l}11 \\
\text { KV }\end{array}$ & 10.69 & 96.8 \\
\hline
\end{tabular}

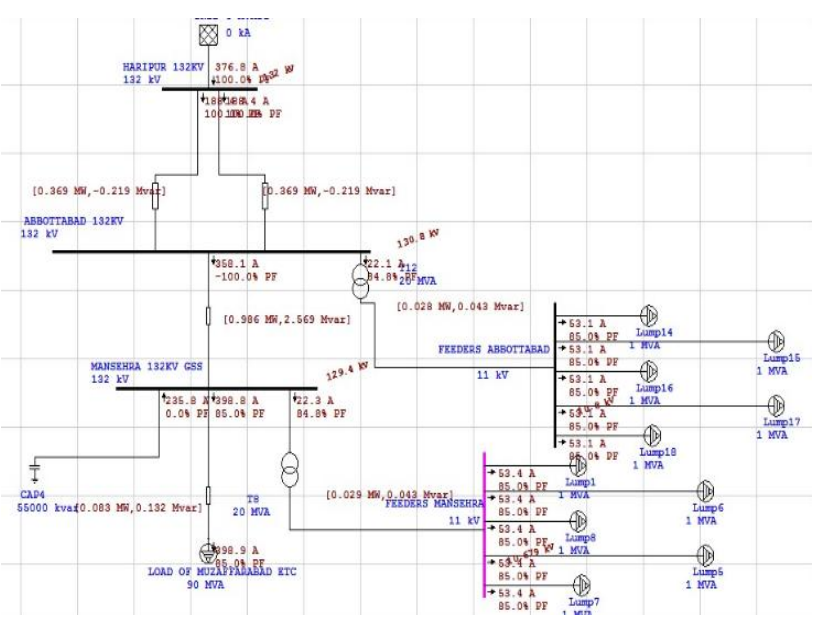

Figure 9. After Conductor Replacement approach

From Table 9 and 10 it is clear that befor conductor replacement the system in overloaded and in critical condition as most of the buses and feeders are working under voltage while after the replacement of conductor it is clearly seen from the simulation results in figure 9 and in table 10 that the system came out of critical position.

TABLE X. SimUlation RESUlts AFTER CONDUCTOR REPLACEMENT APPROACH

\begin{tabular}{|c|c|l|c|c|c|c|}
\hline Device ID & Status & Type & $\begin{array}{l}\text { Conditi } \\
\text { on }\end{array}$ & $\begin{array}{l}\text { Limi } \\
\text { t }\end{array}$ & $\begin{array}{l}\text { Operati } \\
\text { ng }\end{array}$ & $\begin{array}{l}\text { \%Ope } \\
\text { rating }\end{array}$ \\
\hline Bus 4 & $\begin{array}{c}\text { Marg } \\
\text { inal }\end{array}$ & BUS & $\begin{array}{c}\text { Under } \\
\text { voltage }\end{array}$ & $\begin{array}{c}132 \\
\text { KV }\end{array}$ & 129.132 & 97.8 \\
\hline $\begin{array}{c}\text { Mansehr } \\
\text { a Feeder }\end{array}$ & $\begin{array}{c}\text { Marg } \\
\text { inal }\end{array}$ & BUS & $\begin{array}{c}\text { Under } \\
\text { voltage }\end{array}$ & $\begin{array}{c}11 \\
\text { KV }\end{array}$ & 10.579 & 96.11 \\
\hline
\end{tabular}

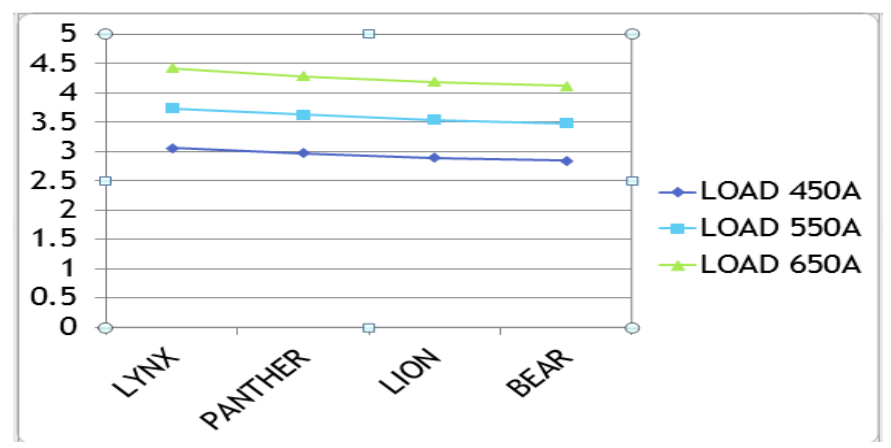

Figure 10. Differents consuctors effects upon the losses.

From figure 10 we can easily see that the GSS voltages of Mansehra and Abbottabad are in critical condition and less than $119 \mathrm{KV}$, and as we replace the conductor using simulation all the voltage of Bus Bars of GSS came to normal range.the losses of the transmision network decreases upto $4.1 \%$ after the replacement of conductor and the load handling capability of the system increase from 465A to 700A.

\section{CONCUSLION}

From the whole simulation and results it is conclude that thier are various factors responsible for $\mathrm{T} \& \mathrm{D}$ losses which need to be eliminated. The approaches taken by government over the years in Pakistan has created an inefficient distribution system having very high $\mathrm{T} \& \mathrm{D}$ losses and poor quality and reliability of power supply to consumers. The whole power system network needs proper up-gradation and overhauling because this system is very weak and have a lot of severe places. PESCO is on second number in the whole ten no of discos whose losses is more the $34 \%$. To reduce these losses the renewable integration, conductor replacement, increasing voltage level and replacement of these old vintage system is needed. The area which is anlyse in this research analysis has many potential regarding power generation and with each Integration of the generation we can solve the critical condition of power system. the most fesible and long term method is to penetrate power from Allai khwar power plant if not than conductor replacement is the most Economical method which can mitigate this issue for about 20 years of future demands.

\section{ACKNOWLEDGMENT}

The research has been carried out and supported by USPakistan Center for Advanced Studies in Energy, UET Peshawar. I am thankful to USAID and USPCASE UET Peshawar for the opportunity provided to complete my postgraduation. I am very nuch grateful to my supervisor Dr. Abdul Basit for his support throughout my research.

\section{REFERENCES}

[1] Bhatti, S.S., et al., Electric power transmission and distribution losses overview and minimization in Pakistan. International Journal of Scientific \& Engineering Research, 2015. 6(4): p. 1108-1112.

[2] Kanagawa, M. and T. Nakata, Assessment of access to electricity and the socio-economic impacts in rural areas of developing countries. Energy policy, 2008. 36(6): p. 2016-2029.

[3] Lopes, J.P., et al., Integrating distributed generation into electric power systems: A review of drivers, challenges and opportunities. Electric power systems research, 2007. 77(9): p. 1189-1203.

[4] Nair, N.-K.C. and L. Zhang, SmartGrid: Future networks for New Zealand power systems incorporating distributed generation. Energy Policy, 2009. 37(9): p. 3418-3427.

[5] Quezada, V.M., J.R. Abbad, and T.G.S. Roman, Assessment of energy distribution losses for increasing penetration of distributed generation. IEEE Transactions on power systems, 2006. 21(2): p. 533-540.

[6] Haseeb, M. and S.A.R. Kashif. Transition to competitive power market framework-A case study of Pakistan. in 2018 International Conference on Computing, Mathematics and Engineering Technologies (iCoMET). 2018. IEEE.

[7] $\mathrm{Xu}, \mathrm{S}$. and $\mathrm{W}$. Chen, The reform of electricity power sector in the PR of China. Energy Policy, 2006. 34(16): p. 2455-2465.

[8] Roberts, J.M. and H. Sattar, Pakistan's Economic Disarray and how to Fix it. 2015: Heritage Foundation.

[9] Parmar, J., Total losses in power distribution and transmission lines. Trans - mission and Distribution Electrical Engineering Portal (EEP), 2013. 
[10] Blavette, A., et al. Analysis of the flicker level generated by the gridconnection of a fleet of electric vehicles. in 2016 IEEE PES Innovative Smart Grid Technologies Conference Europe (ISGT-Europe). 2016. IEEE.

[11] Chiradeja, P. Benefit of distributed generation: A line loss reduction analysis. in 2005 IEEE/PES Transmission \& Distribution Conference \& Exposition: Asia and Pacific. 2005. IEEE.

[12] Kessides, I.N., Chaos in power: Pakistan's electricity crisis. Energy policy, 2013. 55: p. 271-285.

[13] Eisenstadt, W.R. and Y. Eo, S-parameter-based IC interconnect transmission line characterization. IEEE transactions on components, hybrids, and manufacturing technology, 1992. 15(4): p. 483-490.

[14] Sheen, D.M., et al., Current distribution, resistance, and inductance for superconducting strip transmission lines. IEEE Transactions on Applied Superconductivity, 1991. 1(2): p. 108-115.

[15] Tsuk, M.J. and J.A. Kong, A hybrid method for the calculation of the resistance and inductance of transmission lines with arbitrary cross sections. IEEE Transactions on microwave Theory and Techniques, 1991. 39(8): p. 1338-1347.

[16] Chang, W., The inductance of a superconducting strip transmission line. Journal of Applied Physics, 1979. 50(12): p. 8129-8134.

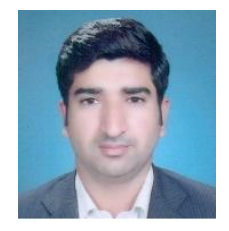

Tariq Ahmad: The author was born in KPK province, District Buner, Pakistan in the year of 1991. He did his matriculation from "Falcon Public School". Afterwards, He pursued his Higher secondary education in Pre-Engineering from "Quaid azam group of school and colledges swabi”, Pakistan. After that He did his Bachelors Degree in Electrical Power Engineering from "COMSATS" Abbottabad, Pakistan. Recently, He has completed his Master's in Electrical Energy System Engineering from USPCAS-E UET Peshawar, Pakistan. Recently, the author started his professional career as Assistant Direrctor(E)/Junior Engineer in a Public sector organistation WAPDA. 